\section{DIGITAL COMMONS \\ @ UNIVERSITY OF SOUTH FLORIDA}

\section{ABO: Interactive Journal for Women in the Arts, 1640-1830}

Volume 2

Issue 1 Volume 2.1 (Spring 2012): Open Access

Article 16

2012

\title{
Separated by Their Sex: Women in Public and Private in the Colonial Atlantic World, by Mary Beth Norton
}

\author{
Leigh Johnson \\ Marymount University, leigh.johnson@marymount.edu
}

Follow this and additional works at: https://digitalcommons.usf.edu/abo

Part of the Dramatic Literature, Criticism and Theory Commons, Educational Methods Commons, Feminist, Gender, and Sexuality Studies Commons, and the Literature in English, British Isles Commons

\section{Recommended Citation}

Johnson, Leigh (2012) "Separated by Their Sex: Women in Public and Private in the Colonial Atlantic World, by Mary Beth Norton," ABO: Interactive Journal for Women in the Arts, 1640-1830: Vol.2: Iss.1, Article 16.

http://dx.doi.org/10.5038/2157-7129.2.1.15

Available at: https://digitalcommons.usf.edu/abo/vol2/iss1/16

This Reviews is brought to you for free and open access by Digital Commons @ University of South Florida. It has been accepted for inclusion in ABO: Interactive Journal for Women in the Arts, 1640-1830 by an authorized administrator of Digital Commons @ University of South Florida. For more information, please contact digitalcommons@usf.edu. 
Separated by Their Sex: Women in Public and Private in the Colonial Atlantic World, by Mary Beth Norton

\author{
Keywords \\ Atlantic World, Private Sphere, Public Sphere \\ Creative Commons License \\ (c) $($ ) $\Theta$
}

This work is licensed under a Creative Commons Attribution-No Derivative Works 3.0 License. 
Mary Beth Norton. Separated by Their Sex: Women in Public and Private in the Colonial Atlantic World. Ithaca, NY: Cornell UP, 2011. \$29.95. xxi + 247 pp. ISBN 978-0-8014-4949-9. Reviewed by Dr. Leigh Johnson, Marymount University

Reviewed by Leigh Johnson, Marymount University

In Separated by Their Sex: Women in Public and Private in the Colonial Atlantic World, Mary Beth Norton traces the counter currents that led to women's relegation to the private sphere of the family and exclusion from public commentary on political events. Starting with the assumption in the early seventeenth century that a woman has a place as a state and political actor if she has high status, Norton proceeds to show how initially subtle shifts in perceptions of women's actions alter the claim to political commentary by women. Using a variety of historical events and texts on both sides of the Atlantic from the period 1640-1760, Norton crafts a nuanced argument regarding the emergence of a gendered public/private binary and rhetorical femininity.

The strengths of such an approach are numerous. From the selection of historical examples, many stand on their own as rhetorically interesting and useful for scholars looking to connect the events of colonial America to Restoration England. The most important assertion Norton makes is to suggest that prior to about 1700 , there was no gendered distinction between public and private; rather, women with high status have more right to act than men with lower status. For instance, she comments on Lady Frances Berkeley's actions to shame her cousin Nathaniel Bacon, "Her worldview, as disclosed by the content of her slanderous remarks and her motives for them, combined rather than separated familial and political matters" (19). Setting up the premise that, at appropriate times, politics and family were the domains of both men and women, Norton then offers corresponding examples that account for class differences and shifting political landscapes, such as Puritan women's defense of the midwife accused of murder, Mistress Tilly, and the lampooned women petitioners of Parliament. Closing the first two chapters, which delineate women's acceptable_but increasingly limited-participation in political affairs, Norton offers the example of Mistress Elinor James. James's broadsides (16811714) offered political commentary unapologetically, until 1700, when James's "newly frequent defenses" of her writing suggest "the rethinking of government's origins and structure after the Glorious Revolution [...] had significant long-term consequences for women's involvement in the public realm" (75). In other words, the restrictions on women's speech were sudden and possibly traumatic to high-status women.

While the counterpoints address the uneven ground on which such shifts in thinking occur, they make a parsimonious argument difficult. Norton handles this challenge well in the pivotal third chapter. Drawing on the success of John Dunton's Athenian Mercury, Norton traces emergent beliefs about private space as the gendered realm for female concerns and activities. Dunton's Mercury answered questions by and about women as part of the Ladies Issue series, but more strikingly, the editors corresponded with intelligent, educated women throughout the 1690s. However, Norton points out, these questions had already defined women's issues as those outside of politics - so the home, love, marriage, and children. The fundamental moment for a nuanced argument of private, gendered space comes with Dunton's 1702 pamphlet, Petticoat- 
Government, in a Letter to the Court Ladies. Queen Anne was "a monarch who on the one hand was a wife, legally subject to her husband under the law, and who on the other was the supreme ruler of the land, in which her husband had no political authority" (100). Dunton deals with this question by separating them into public and private territory, a move Norton claims, marks "the conceptual relegation of all women, including aristocrats and excluding only hereditary monarchs, to a sphere termed private that was confined to familial affairs ... [and that which would be] a significant barrier to women's engagement with the public realm" (104, emphasis added). The concept of private space for women also serves the purpose of removing men from the shared responsibility of the household, which had, up to the late seventeenth century, been viewed as equally distributed between men and women.

Shoring up the gendered distinctions in private and public, Norton turns to the more satirical treatment women's political participation received in the eighteenth century. Publications, such as the Tatler and the Spectator continued to relegate women's participation to the private sphere. Usefully, Norton returns to the cross-currents of transatlantic thought, pointing out the popularity of such journals in the southern colonies. Her study of women's letters of the American Revolution extends this analysis to suggest that women realized that their opinions and comments about military and government activity would be largely unwelcome. The discussion of colonial newspapers and the adopted pose of rhetorical femininity of many male writers is a fascinating addition to the scholarly work of the pre-Revolutionary period in America. Fitting with other studies of women's rhetorical conduct, the ambiguous authorship of rhetorical femininity is most significant for its commentary on subjects' suitability for women's opinions. Norton comments, "The ability of women to reply to published observations on their sex was never publicly called into question" (159). This, along with her discussion of larger colonial houses and tea-drinking as a phenomenon, suggests that women retained some possibility of speech even within a tightening sphere of their political and social behavior.

In tracing the use of the gendered private into the lexicon, Norton offers a cogent, highly readable, applicable understanding of the intellectual, political, and rhetorical shifts that account for the emergent transatlantic acceptance of the separate spheres. However, even within this paradigm, Norton foreshadows the nineteenth-century rebellion against these rigid dictates. By revealing the suddenness of this kind of binary thinking, Norton suggests how coordinated usages of words and concepts may serve to change an entire paradigm of acceptable behavior for state and family actors. 